\title{
Twice Poisoned Bhopal: Notes on the Continuing Aftermath of the World's Worst Industrial Disaster
}

\author{
Chandana Mathur \\ New School University \\ Ward Morehouse \\ Council on International and Public Affairs, New York
}

In one horrifying night and through the long misery of nearly eighteen years of injustice that have followed it, the city of Bhopal in India can be said to have experienced the head-on impact of world historical and political economic processes. In 1969, Union Carbide India Limited (UCIL) set up a plant to manufacture the pesticide Sevin in Bhopal, with the permission and, indeed, the encouragement of the Indian government. This was the heyday of the Green Revolution, introduced in India in the mid-1960s and based on HYV (high-yielding variety) seeds, chemical fertilizers, pesticides, and vastly increased irrigation. The disastrous social and environmental consequences of this technological choice (made by Indian planners, ${ }^{1}$ with backing from international agencies such as the World Bank and the Ford and Rockefeller foundations) are well documented, ${ }^{2}$ but it is not always remembered that the Bhopal gas tragedy has its roots in the same narrative. The design of the Bhopal plant, as well as the policies relating to its maintenance and operation, were in keeping with the double-standard often applied by transnational corporations in their Third World outposts, where environmental, worker, and community safety issues may be seen as less pressing than at home. ${ }^{3}$ Finally, for nearly two decades after the deadly gas leak, the legal struggle to make the Union Carbide Corporation (the parent corporation of UCIL) accountable for the tragedy has played out against the changing backdrop of the demise of the Soviet bloc and the introduction of economic liberalization in India. Even though the new economic reforms were formally put in place in India only in July 1991, the writing on the wall had been quite clear in the years preceding. The Indian State's unwillingness to discourage foreign private investment has been a crucial factor in the continuing injustice in Bhopal.

To begin at the grim beginning, the lethal gases that leaked from the Union Carbide pesticide plant in Bhopal in the dark early hours of December 3, 1984 killed several thousand people and injured more than half a million. ${ }^{4}$ This accident - the world's worst industrial disaster-was caused by a runaway reaction in a gigantic storage tank in which forty-two tons of methyl isocyanate (MIC) were stored. The concrete storage tank burst open and a huge poison cloud of MIC and other breakdown chemicals drifted across the city of Bhopal, destroying every form of life it encountered. Although the exact death toll will never be 
known, it is now officially admitted to be more than 5,000, while activists estimate that the figure may be closer to $20,000 .^{5}$ Those who survived that night suffered severe damage to their lungs and eyes, as well as to their gastrointestinal, reproductive, immune, neural, and other systems. ${ }^{6}$

In keeping with the social geography characteristic of communities living with chemical industries, the Union Carbide facility was surrounded by some of the poorest neighborhoods in Bhopal. Jaiprakash Nagar, Chola Kenchi, Kazi Camp, Arif Nagar and others were among the worst-affected areas; their residents were mainly daily wage workers whose ability to perform hard manual labor has been impaired by gas-related injuries and chronic illnesses. According to a 1998 report:

Over $70 \%$ of the exposed population has been in the unorganized sector, with people earning subsistence wages through day labor or petty trade. A large number of men and women who pushed hand carts, carried loads, dug soil, repaired cars and did other jobs can no longer pursue their trades after being exposed to Carbide's gases ... the loss of regular income has driven tens of thousands of families to chronic starvation conditions. Loss of income also makes people borrow money from local money lenders who charge up to $200 \%$ interest so that chances of paying back are low and debts keep growing. ${ }^{7}$

Yet activist victims in Bhopal have persevered in their struggle for justice for nearly two decades, holding together in such organizations as Bhopal Gas Peedit Mahila Udyog Sangathan (Bhopal Gas-Affected Women Workers' Union) and Bhopal Gas Peedit Mahila Stationery Karamchari Sangh (Bhopal GasAffected Women Stationery Workers' Organization).

Union Carbide's immediate response was to withold important information about the harmful effects of MIC, the main chemical in the poison cloud. Plant officials at the time of the leak stated that MIC was no worse than a "potent tear gas." Union Carbide's doctors denied the possibility of cyanide poisoning (which caused many deaths that might have been averted if sodium thiosulphate - a cyanide antidote — had been administered), and, later, statements were made by their American medical experts, Drs. Peter Halberg and Hans Weill, that MIC has no long-term medical effects. Union Carbide was quick to shift the blame to those it had killed and maimed in the desperately poor communities near the Bhopal plant; their very poverty and helplessness were turned into accusations against them. Bud Holman, attorney for Union Carbide, described the Bhopal victims in these terms: "Some have tuberculosis, which is endemic in that area, some have emphysema, which is endemic in that area, some have malnutrition, which is a troublesome thing in that area. Each individual history has to be examined in order to determine what damage he has, or whether he has a claim or not. The claims include a considerable number of fraudulent claims, we expect."8

Again, Union Carbide's medical expert, Dr. Peter Halberg, told a reporter, "The MIC produced a heavy cloud which settled very close to the earth, killing 
children because of their immature lungs, the elderly because of their diminished lung capacity, those who ran because their lungs expanded too quickly, and small animals. The survivors included those people who stood still and covered their faces with handkerchiefs. ..."9 In other words, it was their own fault for being too young, too old, or too medically untrained to know that their best bet was to stand still as the deadly cloud engulfed their city. It has been pointed out that the corporation was well aware of the dangerous nature of MIC. To cite only one example, the results of Carbide-sponsored research undertaken at the Mellon Institute in 1963 (one of the many studies commissioned by the corporation over the years) included the statement that "methyl isocyanate appears to be the most toxic member of the isocyanate family ... [It] is highly toxic by both the pectoral and skin penetration routes and presents a definite hazard to life by inhalation."10 By contrast, the findings announced by Carbide scientists in the years after the disaster tended to minimize the degree of long-term damage perpetrated by the Carbide gases. Even now, despite repeated requests by victims' groups, the corporation continues to invoke the Trade Secrets Act to justify their withholding of medical information and research on MIC. ${ }^{11}$

In the immediate aftermath of the disaster many medical professionals came into Bhopal to offer their services, collect crucially important survey information, monitor the health status of the gas-affected victims, and write critical affidavits for the case against Carbide. Once their activities in the Bhopal were brought to a halt by the Indian government, they continued with laboratory research and the publication of findings that counter the false sense of security being fostered by Carbide researchers. ${ }^{12}$ Ten years after the disaster the International Medical Commission on Bhopal (IMCB) went to Bhopal to chronicle the long-term health consequences of the gas leak. Formed by two eminent epidemiologists at the invitation of victim groups, the International Medical Commission on Bhopal was an independent inquiry commission consisting of fifteen medical professionals from twelve countries. Their final report, released in New York in December 1996, showed that as many as 50,000 survivors may be permanently disabled, either partially or totally. While reaffirming the previously known facts about the severe damage caused by the Union Carbide gases to the lungs and eyes of the victims, the Commission also reported widespread neurotoxicological damage. One major concern for the Commissioners was the health status of children: since nobody under the age of eighteen had been registered as a gas victim, there had been no official recognition of their illness and, of course, no compensation. The Commission strongly recommended the registration, compensation and ongoing monitoring of those survivors who were in utero or under age eighteen at the time of the disaster and of the children of survivors. They found medical care and treatment of chronically ill Bhopal survivors to be lacking in continuity; their medical conditions were seldom treated as gas exposure-related. One of the major recommendations of the Medical Commission was the establishment of a network of community-based health centers to serve the chronic health care needs of the victims. ${ }^{13}$ Although there has been no official response to this recommendation, a voluntary initiative 
known as the Sambhavna Trust set up the Bhopal People's Health and Documentation Clinic in 1996. The Sambhavna Clinic provides free medical care to Bhopal survivors through modern medicine as well as traditional Indian therapies and also carries out health survey and education in the affected communities, monitors continuing exposure related deaths, conducts research, runs a documentation unit, organizes health camps, and so on. Their efforts reach a small fraction of the survivors who are in need of appropriate medical attention and underscore the indifference to the survivors' circumstances shown by the Union Carbide Corporation and by the Indian government.

There is a good deal of evidence to show that the Union Carbide Corporation had been negligent in the design, maintenance, and operation of the Bhopal plant. The most egregious design blunder was the US management's decision to store MIC in Bhopal in 15,000 gallon tanks rather than in smaller individual containers, a decision which specifically overrode the objections of Carbide's managers in India. ${ }^{14}$ The company chose the more dangerous option because they were intending to manufacture MIC not only for the plant's own use but also for sales to other industrial customers. A cost-cutting drive initiated at the corporate headquarters in Danbury, Connecticut, in 1980 had reduced the size of work and maintenance crews at the Bhopal plant's MIC unit, and the refrigeration unit that might have kept the MIC at safe storage temperatures had been shut off to save on expenses. ${ }^{15}$ The runaway reaction occurred when water used for washing the lines accidentally leaked into the tank containing MIC at ambient temperature. Although their designed capacities may have been inadequate for such a reaction, none of the MIC unit's safety systems were working: ${ }^{16}$ the scrubber which was supposed to neutralize escaping gases with caustic soda was empty, and the flare tower designed to burn off gases from the scrubber was under repair. The alarm system had been turned off because it had been going off very frequently in response to numerous smaller leaks in the preceding months. Since the night of the disaster, the corporation has directed its considerable resources toward lawyers and public relations experts in an effort to escape legal liability and bury the memory of Bhopal.

As news of the disaster reached other parts of the world, droves of American claims lawyers descended on the city, promising victims untold riches from personal injury lawsuits against Union Carbide. In order to protect the victims from unscrupulous lawyers the Government of India passed the Bhopal Gas Leak Disaster (Processing of Claims) Act in March 1985, which stipulated that the government would, in its parens patriae role, pursue justice for and provide assistance to the victims of the disaster. The reasoning behind this was that the government was in a better position than the impoverished and illiterate typical victim to arrange for adequate legal representation and to pursue a powerful multinational corporation through the byways of justice. The pursuit was vigorous in the beginning: in a New York District Court in 1985, the Indian government successfully countered Carbide's efforts to shift the blame entirely on Union Carbide India Limited (UCIL), its Indian subsidiary, which with its far smaller assets could not have been expected to pay any substantial amount of compen- 
sation to the victims. The Indian government was interested in engaging in a struggle for compensation with the Union Carbide Corporation, not its much smaller subsidiary, and would have also preferred to pursue the case in a US court, where the laws and standards of compensation for toxic exposure cases and procedures for class action litigation with many victims were more fully developed than they were in India. So the federal District Court in New York was treated to the piquant spectacle of the Indian government arguing in an American court that the Indian legal system was shoddy and inadequate, while Carbide's lawyers expressed their highest admiration for the standards of law and justice in India. Judge John Keenan ruled that the issue concerned Union Carbide Corporation, not just UCIL, but that it could be decided in the Indian courts.

Union Carbide's legal strategy has been fairly simple: to outlast its victims by delaying the litigation process and to keep the case from going to trial. Once the case was transferred to India, the corporation would keep challenging the jurisdiction of the Indian courts by alleging that its due process rights were being violated. This tactic was designed to threaten the Indian government with many a time-consuming legal journey back through the US courts. Also, in early 1985, Carbide's lawyers began to bat around the proposition that the gas leak was a deliberate act of sabotage by a disgruntled employee. While this sabotage theory has paid off richly in public relations terms and still remains the first "fact" that the company states about the Bhopal gas tragedy, Carbide has been very anxious to keep it out of the courtroom, partly because of its inherent falsehood $^{17}$ and partly because an act of sabotage by an employee is no defense against liability under Indian law.

The litigation began in the District Court of Bhopal in 1986, which ordered Carbide to pay substantial interim relief $-\$ 270$ million - to the devastated victims of the disaster. Predictably, the corporation appealed the court's ruling and took the matter to the Madhya Pradesh High Court. The High Court reduced the amount of interim payment somewhat, and in keeping with its stalling tactics, Carbide once again appealed the ruling. The matter of interim relief was then taken to the Supreme Court, which suddenly and surprisingly ruled in February 1989 that the Indian government and Union Carbide should agree to a settlement which required the corporation to pay a mere $\$ 470$ million in total damages. This amount was insufficient even to pay for the basic medical treatment that Bhopal victims required on account of gas exposure and is pitifully small compared to the damages paid to the victims of other major industrial disasters. The comparison with Exxon is particularly stark: for the Valdez spill, where no human lives were lost, a US court found Exxon liable for \$5 billion in damages, while the over 600,000 claimants in the Bhopal case were being asked to share in the sum of $\$ 470$ million. It was immediately understood that the Union Carbide Corporation had got off very lightly for the death and devastation it caused in Bhopal: Carbide's stock price rose by two dollars a share in the New York Stock Exchange on the day that the settlement was announced. All of the amount except some \$20 million was covered by Carbide's liability insurance and small amounts it had set aside each year while the litigation dragged on. ${ }^{18}$ 
We can only speculate as to the reasons behind the abrupt Supreme Court decision. Corruption is sometimes blamed, as are political pressures. It is possible that the Supreme Court bench may have felt that the Bhopal victims had waited long enough. But there is also the specific historical context of an Indian state which had just then begun to abandon its established economic policy of import substitution for a neoliberal regime contingent on the country's ability to attract foreign capital.

Following the filing of review petitions by victims' groups the Supreme Court upheld the settlement in October 1991, but tried to mitigate it somewhat. The most significant changes were that Carbide no longer had immunity from criminal charges in the Bhopal case, the right of unborn children to reopen litigation was restored, and the government was asked to provide insurance coverage to the victims. Since that time, the Union Carbide Corporation has been absconding from the criminal charges of culpable homicide and grievous harm pending against it in the Magistrate's Court in Bhopal. While accepting the Indian Supreme Court's ruling upholding the settlement, the corporation has chosen to overlook the fact that the same judgement had rendered them subject to criminal proceedings in India. Although many different political parties have risen to power in India in these intervening years, it is significant that no Indian government since that time has pushed for these proceedings to begin or sought the extradition from the US of Warren Anderson, the CEO of Union Carbide at the time of the disaster. As I write, there has been a disturbing new development: the Indian government is considering diluting substantially the charges against Anderson. This has provoked protests and hunger strikes from the Bhopal survivors and their allies, some as far away as Seadrift, Texas.

The disbursement of the $\$ 470$ million settlement by government agencies has been a convoluted and corruption-riddled process, at the end of which injured survivors come away with a sum of money that is not even adequate to pay for the medical costs they have incurred since 1984. There are no funds available to provide for the economic rehabilitation of the hundreds of thousands of survivors whose injuries have prevented them from working or to provide compensation for the years of suffering they have endured. People continue to die from gas exposure-related injury and illness: as many as thirty each month. ${ }^{19}$

At the end of 1999 a new lawsuit was filed in New York on the behalf of Bhopal victims charging Union Carbide with "reckless and depraved indifference to human life." Soon after this, in February 2001, the Union Carbide Corporation merged with the Dow Chemical Corporation. It was feared that the Dow-Carbide merger could make the legal pursuit more complicated: Dow spokespeople have claimed that they cannot be held liable for an old accident in a Carbide plant, and Carbide officials insist that the entity legally responsible for Bhopal no longer exists. Nonetheless, in November 2001 a US federal appeals court upheld seven of the fifteen complaints filed by the Bhopal plaintiffs, finally opening up a sliver of possibility that a trial might take place in the US. For the first time, Carbide has been directed by a court of law to furnish evidence regarding some of the claims they have made. 
As long ago as their April 1996 annual shareholders' meeting, William H. Joyce, the CEO of Union Carbide Corporation, had told one of us that the company had no intention of doing anything more for the Bhopal victims. It remains to be seen whether the US judicial system will be any more effective than its Indian counterpart in compelling the corporation to rethink this position. In the meanwhile, the Bhopal disaster stands as a powerful reminder of the impunity with which global corporations can, through gross negligence, violate fundamental human rights in the Third World.

\section{NOTES}

1. This was done at least partially in order to avoid the political vulnerability that dependence on imported foodgrains might bring. Marshal Windmiller, conversation with one of the authors.

2. See, for example, Vandana Shiva, Violence of the Green Revolution (New York, 1991).

3. For detailed accounts of the corporation's disregard for safety standards at the Bhopal plant, see David Dembo, Ward Morehouse and Lucinda Wykle, Abuse of Power. Social Performance of Multinational Corporations: The Case of Union Carbide (New York, 1990), 87-91; Ward Morehouse and Arun Subramaniam, The Bhopal Tragedy: What Really Happened and What It Means for American Workers and Communities at Risk (New York, 1986), 2-8; Ruth Norris et al., Pills, Pesticides and Profits, (Croton, NY, 1982).

4. Paul Watson, "Cloud of Despair in Bhopal," Los Angeles Times, August 30, 2001.

5. Ibid.

6. The most commonly noted medical condition for Bhopal survivors is lung damage, and damage to the respiratory system more generally. The incidence of pulmonary tuberculosis among the exposed population has been found to be more than three times the national average [Bhopal People's Health and Documentation Clinic, The Bhopal Gas Tragedy 1984-?: A Report from the Sambhavna Trust, Bhopal, India (Mumbai, 1998), 10].

7. Bhopal People's Health and Documentation Clinic, The Bhopal Gas Tragedy 1984-? (Mumbai, 1998), 12.

8. Cited in Dembo, Morehouse and Wykle, Abuse of Power (New York, 1990), 95.

9. Cited in ibid., 95.

10. Cited in ibid., 94.

11. Satinath Sarangi, "Criminals I Have Met," Ecologist Asia, November/December 2000, vol. 8, no. 6, 44. Also, online at www.sanctuaryasia.com/features/featurecategory.php?id=14

12. See, for example, Diana Anderson, Shobha Goyle, B. J. Phillips, A. Tee et al., "Effects of Methyl Isocyanate on Rat Muscle Cells in Culture," British Journal of Industrial Medicine, 1988, 45: 269-74.

13. "Twelve Years After Bhopal" Report of the International Medical Commission on Bhopal, International Perspectives in Public Health, Vols. 11, 12.

14. Affidavit of former UCIL manager Edward Munoz, cited in Dembo, Morehouse and Wykle, Abuse of Power (New York, 1990), 87.

15. Ibid., 88 .

16. Ibid., 87.

17. For refutations of the sabotage theory, see the account of a former worker at the Bhopal plant: T. R. Chouhan et al., Bhopal: The Inside Story (New York, 1994). Also, Morehouse and Subramaniam, The Bhopal Tragedy: What Really Happened (New York, 1986), 11-12.

18. "Union Carbide Agrees to Settle All Bhopal Litigation for $\$ 470$ million," Wall Street Journal, February 15, 1989.

19. Madhya Pradesh Government Department of Bhopal Gas Tragedy Relief and rehabilitation, 2001 Annual Report, 23. 